\title{
THE ALIEN CHINESE MITTEN CRAB, ERIOCHEIR SINENSIS (CRUSTACEA: DECAPODA: BRACHYURA), IN THE THAMES CATCHMENT
}

\author{
PAUL F. CLARK, PHILIP S. RAINBOW*, RONI S. ROBBINS, BRIAN SMITH*, \\ WILLIAM E. YEOMANS ${ }^{\dagger}$, MYLES THOMAS $^{\ddagger}$ AND GINA DOBSON
}

The Natural History Museum, Cromwell Road, London, SW7 5BD. *School of Biological Sciences, Queen Mary \& Westfield College, University of London, London, E1 4NS. 'Environment Agency, Biology Laboratory, Reading, RG2 0SF. ${ }^{\ddagger}$ Environment Agency, Apollo Court, 2 Bishops Square Business Park, St Albans Road West, Hatfield, Herts, AL10 9EX

Eriocheir sinensis, the Chinese mitten crab, is a native of east Asia and predominantly lives in freshwater but migrates seawards to breed. In 1912 a specimen was collected in the River Aller, a tributary of the Weser, Germany and now this exotic species has a European distribution from Finland to the Atlantic coast of southern France. In the UK, the mitten crab has been reported from the Humber, Medway and Thames catchments. Although the population in Thames had remained low, recent evidence suggests it is increasing, which has potential environmental implications.

\section{INTRODUCTION}

The Chinese mitten crab, Eriocheir sinensis H. Milne Edwards, 1854, originates from the Far East, with a native distribution from the Province of Fukien, China, $\sim 26^{\circ} \mathrm{N}$ northwards to the Korean Peninsula $\sim 40^{\circ} \mathrm{N}$. Mitten crabs are catadromous, spending most of their life in freshwater, returning to the sea to breed. Males and females move downstream during late summer and attain sexual maturity in tidal estuaries. According to Panning (1939), the females are thought to continue seaward after mating, overwintering in deeper water before returning to brackish water in the spring to hatch their eggs. Larval development probably occurs in the lower estuary, with juvenile crabs gradually moving upstream into freshwater to complete the life cycle.

Eriocheir sinensis was introduced into Germany in 1912 (Panning, 1939) and has spread subsequently throughout northern Europe. Its present estimated distribution ranges from Finland (Haahtela, 1963), through Sweden, Russia, Poland, Germany, the Czech Republic (Prague), Netherlands, Belgium and England to France. The southernmost Atlantic coast record is the Golfe de Gascogne (Vigneux et al., 1993), France, but the crab has extended its range via the Garonne canal system to Sigean (Petit, 1960), Languedoc-Roussillon, southern France. The crab has also been reported from North America (Nepszy \& Leach, 1973; Horwath, 1989; Cohen \& Carlton, 1997). 
It was first recorded from the British Isles by Harold (1935), when a specimen was captured on the intake screens of Lots Road Power Station, Chelsea. It has since been reported from the Thames, Medway and Humber catchments and from Southfields Reservoir, near Castleford in Yorkshire.

In the Thames catchment, the mitten crab population remained relatively constant through the 1970s and 1980s. Ingle \& Andrews (1976) recorded three male crabs from the intake screens of the West Thurrock generating power station, located $\sim 36 \mathrm{~km}$ downstream of the City of London. Three years later an ovigerous crab was collected at Southend-on-Sea and a further 20 specimens were noted by Andrews et al. (1982) again from West Thurrock. Additions to The Natural History Museum reference collection prior to 1996 included specimens from the Thames at Twickenham and Thames Ditton and from the grounds of West Middlesex Hospital near Syon Park. Since 1990 increasing numbers of mitten crabs have been collected from the intake screens from Lots Road power station, Chelsea. Figure 1 illustrates the known distribution records of mitten crabs in the Thames catchment up to November 1995.

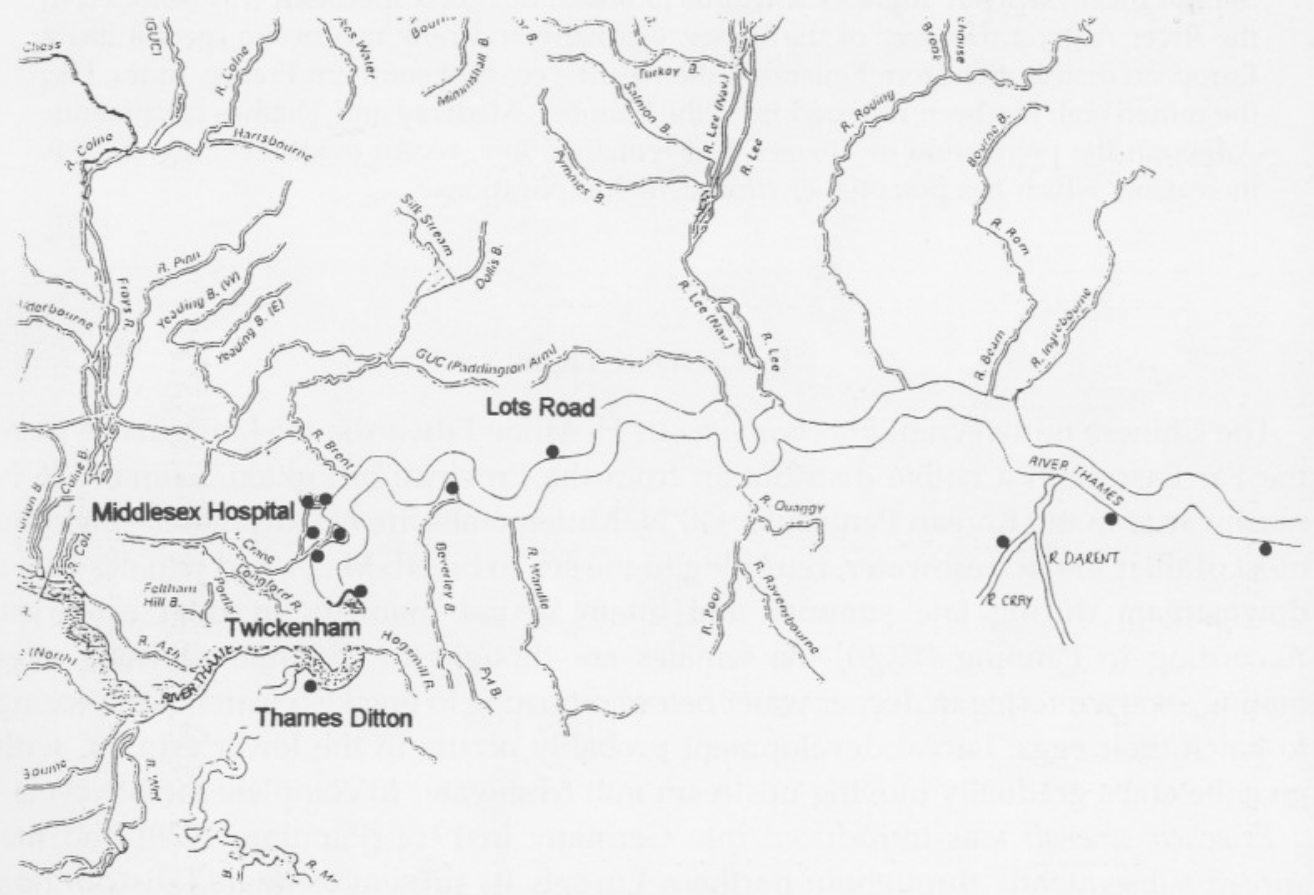

Figure 1. Distribution of Eriocheir sinensis in the Thames catchment from Natural History Museum specimens collected between May 1976 and November 1995.

\section{RESULTS}

In 1996 an appeal was made for mitten crab sightings and from 27 August to 15 November, 162 reports were received. Figure 2 shows the updated distribution in the Thames catchment. Eriocheir sinensis is now known from as far west as the River Colne 


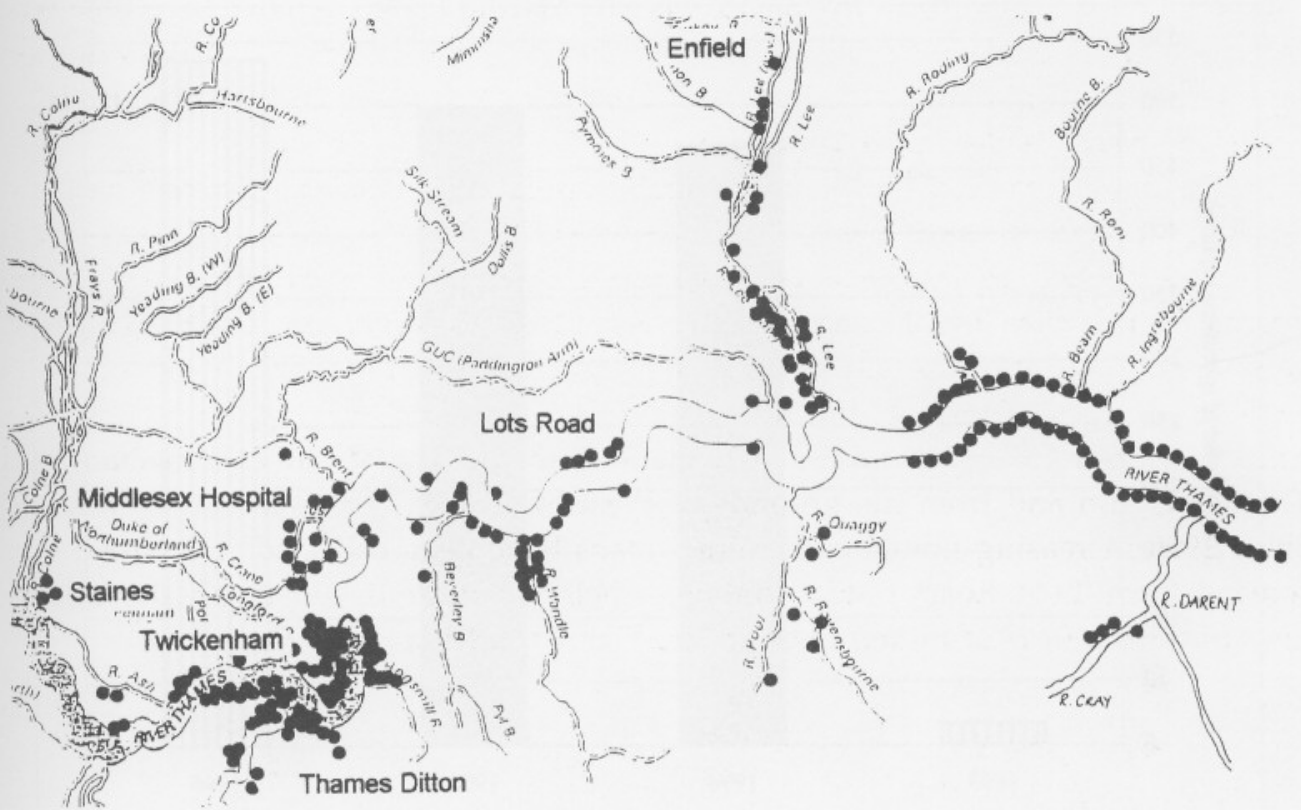

Figure 2. Distribution of Eriocheir sinensis in the Thames catchment from information received between 27 August 1996 and 15 November 1996.

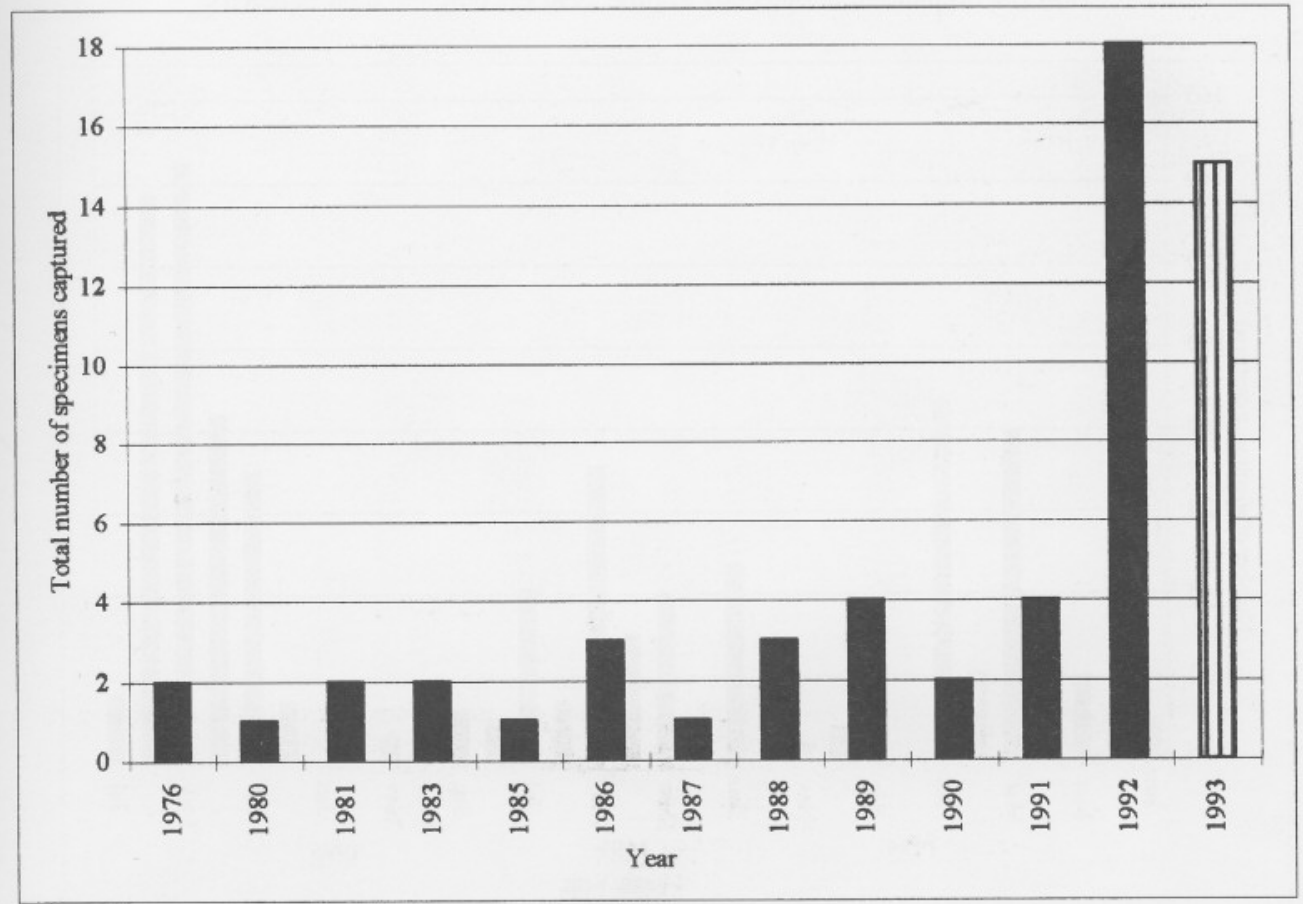

Figure 3. Numbers of Eriocheir sinensis collected at West Thurrock Power Station from 1976 to 31 March 1993 (incomplete data hatched) when electricity generating ceased. 


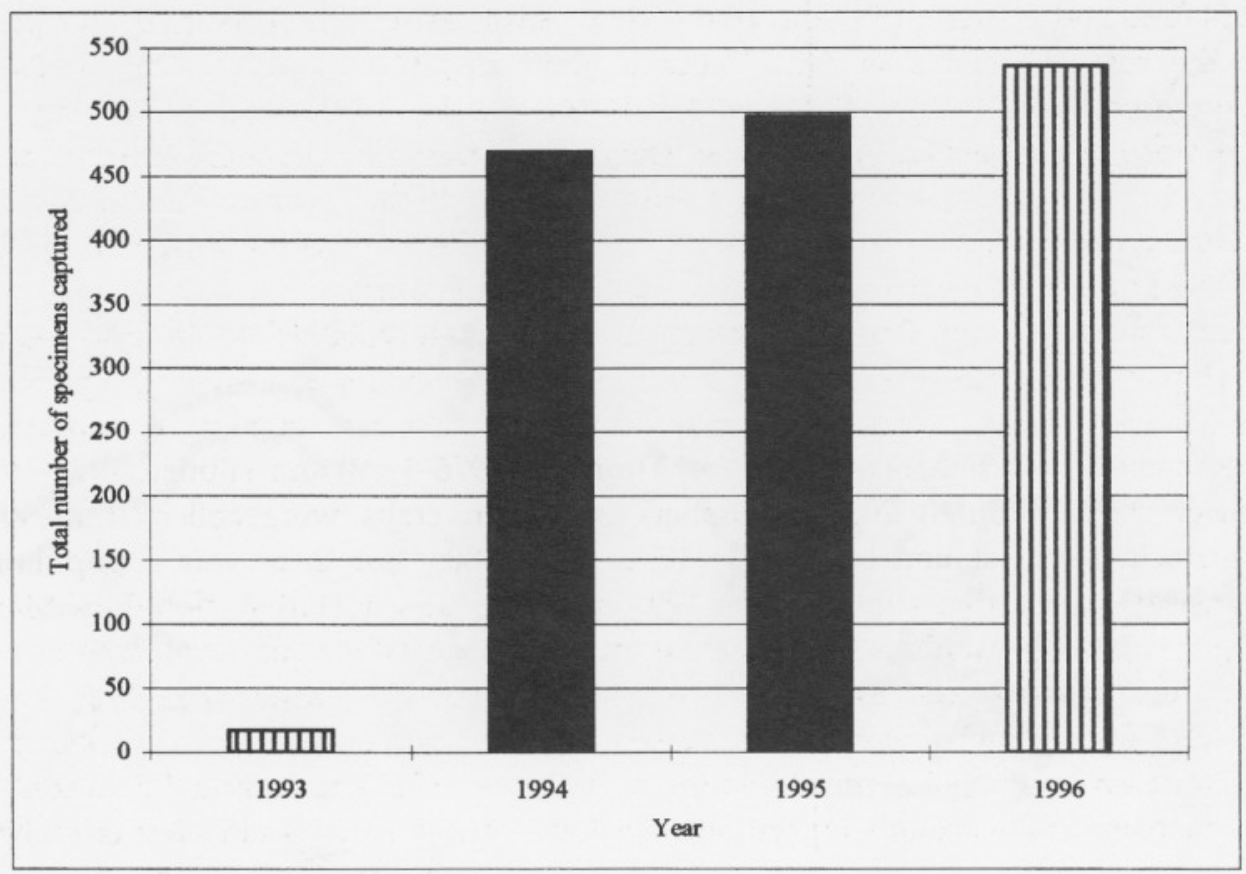

Figure 4. Numbers of Eriocheir sinensis collected annually at Tilbury Power Station from October 1993 (incomplete data hatched) to June 1996 (incomplete data hatched).

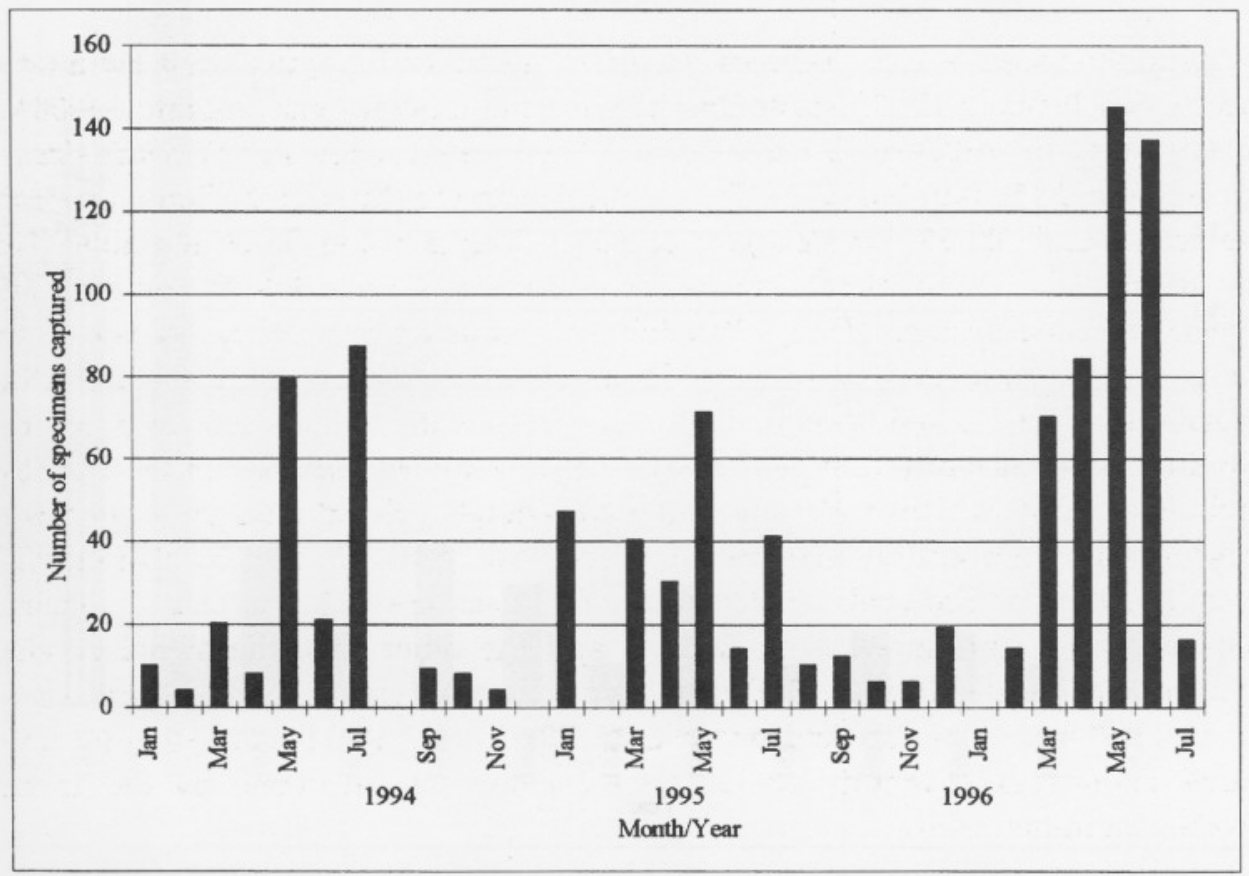

Figure 5. Monthly captures of Eriocheir sinensis from the intake screens at Tilbury Power Station (average number in four hour collections at two week intervals) from January 1994 to July 1996. 
at Staines and is present in most of the Thames tributaries downstream of this point. In the east, the crab has been found in the Cray, Darent, (C. Dutton, personal communication) Quaggy, Pool and Ravensbourne. In the north-east, sightings are common in the rivers Roding and Lee. The most northerly report of E. sinensis is in the River Lee at Enfield, some $15 \mathrm{~km}$ upstream of the River Thames. The survey also recorded E. sinensis in every tributary from Chelsea upstream to Chertsey. The furthest upstream record at Staines is $\sim 65 \mathrm{~km}$ from Tilbury.

The population of Eriocheir sinensis is now firmly established in the Thames catchment and, since 1992, has been increasing in numbers as well as geographical range. Environment Agency records include data on the total number of crabs collected from the filter screens at West Thurrock (1976-1993) and Tilbury (1993-1996) power stations. Small annual numbers of mitten crabs were collected at West Thurrock power station in the late 1970s and 1980s, but there was a population increase in 1992 that continued in 1993 until the power station closed in March (Figure 3). Large numbers of crabs were collected from Tilbury power station in 1994 and 1995 with at least as many in the first half of 1996 when collecting ceased (Figure 4). Figure 5 presents data in terms of the numbers of crabs collected in separate $4 \mathrm{~h}$ counting periods at Tilbury from 1994 to 1996 . The averaged data confirm the increase in crab numbers continued in 1996. The seasonal occurrence of crabs at Tilbury corroborates the view that crabs are migrating through the estuary. Peak numbers appear at Tilbury in May.

\section{DISCUSSION}

The sudden increase in the Thames catchment mitten crab population is a matter of concern. Schellenberg (1928) states that juvenile mitten crabs can migrate $\sim 1000 \mathrm{~km}$ while growing to adult size. Furthermore, Adema (1991) notes that Eriocheir sinensis has been found $1500 \mathrm{~km}$ inland in China, and that in the River Elbe, Germany, crabs have been found $700-780 \mathrm{~km}$ upstream as far as Prague in the Czech Republic. This indicates that the whole of the Thames river system is accessible to invasion and dispersal via canal systems (Petit, 1960) linking catchments is a reality. Moreover, the crab is also capable of crossing dry land to enter new river systems. Further population expansion could eventually threaten freshwater habitats and communities including those currently occupied by the native crayfish Austropotamobius pallipes (Lereboullet, 1858) which is already under considerable threat from four species of foreign crayfish introduced into British rivers. Two of these, the Turkish crayfish Astacus leptodactylus Eschscoltz, 1823 and the European crayfish A. astacus (Linnaeus, 1758) have been introduced from Europe, and the other two, the signal crayfish Pacifastacus leniusculus (Dana, 1852) and the red swamp crayfish Procambarus clarkii (Girard, 1852) from America. Andrews et al. (1982) documented the macrofauna of the Thames Estuary and components of this too could be threatened by the annual migration of mitten crabs. 
A further concern is that E. sinensis is also a burrower (Panning, 1939) which could threaten unprotected engineering earthworks - and which resulted in the banning of live mitten crab imports (see Horwath, 1989) into California in 1987 and subsequently the whole of the US in 1989.

In the Far East E. sinensis is the second intermediate host of the oriental lung fluke, Paragonimus westermanii (Kerbert, 1878), and if the crab is eaten uncooked the parasite can infect humans, causing the disease paragonimiasis. However, establishment of this lung disease in Britain is thought unlikely because $P$. westermanii is specific to a primary intermediate host of aquatic snails assigned to the Thiaridae, and the climate in Britain is too cold for members of this gastropod family.

The population of mitten crabs in the Thames Estuary has increased since 1992 from a previously relatively constant background number. The distribution of E. sinensis in the Thames catchment now extends from Staines in the west and northwards to Enfield with records from most tributaries east of Staines. This alien species has the potential to upset the balance of the resident ecosystems in the Thames and it may compete with the native crayfish in freshwater. Finally, the annual migration of thousands of crabs could affect the macrofaunal community of the estuary.

Richard Bettany of London Transport is thanked for allowing us to collect Eriocheir sinensis from the intake screens at Lots Road power station. This study was supported by the Environment Agency. Opinions expressed in this paper do not necessarily reflect the policies of the Environment Agency.

\section{REFERENCES}

Adema, J.P.H.M., 1991. Krabben van Nederland en Belgie. [Crabs from Holland and Belgium.] Leiden: Nationaal Natuurhistorisch Museum.

Andrews, M.J., Aston, K.F.A., Rickard, D.G. \& Steel, J.E.C., 1982. The macrofauna of the Thames Estuary. The London Naturalist, 61, 30-61.

Cohen, A.N. \& Carlton, J.T., 1997. Transoceanic transport mechanisms: introduction of the Chinese mitten crab, Eriocheir sinensis, to California. Pacific Science, 51, 1-11.

Dana, J.D., 1852. Macroura. Conspectus Crustaceorum, Ec. Conspectus of the Crustacea of the Exploring Expedition under Capt. C. Wilkes, U.S.N. Proceedings of the Academy of Natural Sciences of Philadelphia, 6, 10-28.

Eschscholtz, F.F., 1823. Descriptio novae Astacorum speciei Rossicae. Mémoires de la Société Impériale des Naturalistes de Moscou, 20, 109-110.

Girard, C., 1852. A revision of the North American Astaci, with observations on their habits and geographical distribution. Proceedings of the Academy of Natural Sciences of Philadelphia, 20, 87-91.

Haahtela, I., 1963. Some new observations and remarks on the occurrence of the Mitten Crab, Eriocheir sinensis Milne Edwards (Crustacea, Decapoda), in Finland. Aquilo Societas Amicorum Naturae Oulensis, 1, 9-16.

Harold, C.H.H., 1935. Thirtieth annual report on the results of the chemical and bacteriological examination of the London Waters for the 12 months ending 31 December 1935. Metropolitan Water Board London, p. 101.

Horwath, J.L., 1989. Final Rule on importation of injurious wildlife: mitten crabs. Federal Register: Rules and Regulations, 54, 22286-22289.

Ingle, R.W. \& Andrews, M.J., 1976. Chinese mitten crab reappears in Britain. Nature, London, 263, 638 .

Kerbert, C., 1878. Zur Trematoden-Kenntnis. Zoologischer Anzeiger, Liepzig, 1, 271-273. 
Lereboullet, A., 1858. Description de deux nouvelles espèces d'écrevisse de nos rivières. Mémoires de la Société des Sciences, Agriculture et Arts de Strasbourg, 5, 1-11.

Linnaeus, C., 1758. Systema Naturae per Regna Tria Naturae, Secundum Classes, Ordines Genera, Species, cum Characteribus, Differentiis, Synonymis, Locis, vol. 1, 10th ed. Holmiae: Laurentii Savii.

Milne Edwards, H., 1854. Notes sur quelques Crustacés nouveaux ou peu connus conservés dans la collection du Muséum d'Histoire Naturelle. Archives du Muséum d'Histoire Naturelle, $7,145-192$.

Nepszy, S.J. \& Leach, H.J., 1973. First records of the Chinese mitten crab, Eriocheir sinensis (Crustacea: Brachyura) from North America. Journal of the Fisheries Research Board of Canada, 30, 1909-1910.

Panning, A., 1939. The Chinese mitten crab. Report of the Board of Regents of the Smithsonian Institution (Washington), 3508, 361-375.

Petit, G., 1960. Le crabe chinois est parvenu en Méditerranée. Vie et Milieu, 11, 133-136.

Schellenberg, A., 1928. Krebstiere oder Crustacea. II. Decapoda, Zehnfüßer. Die Tierwelt Deutschlands und der angrenzenden Meeresteile. Jena: Verlag Gustav Fischer.

Vigneux, E., Keith, P. \& Noël, P., ed., 1993. Atlas préliminaire des Crustacés Décapodes d'eau douce de France. Coll. Patrimoines Naturels, 14, Paris: Secrétariat de la Faune et de la Flore, Laboratoire de Biologie des Invertébrés Marins et Maalacologie Muséum National d'Histoire Naturelle, Conseil Supérieur de la Pêche, Ministère de l'Environment. 